\title{
Green competitiveness: the evolution of concept formation
}

\author{
Olena Chygryn ${ }^{1, *}$, Anna Rosokhata ${ }^{1}$, Olena Rybina $^{1}$ and Natalia Stoyanets ${ }^{2}$ \\ ${ }^{1}$ Department of Marketing, Sumy State University, R.-Korsakova Str., 2, Sumy, 40007, Ukraine \\ ${ }^{2}$ Economics and Management Department, Sumy National Agrarian University, Gerasim Kondratieva Str., 160, Sumy, 40000, Ukraine
}

\begin{abstract}
The modern tendencies confirmed the necessity to consider the environmental factors in companies' effectiveness. The goal of the article is to investigate the structural and functional environment of the development of the green competitiveness concept. In the paper were used the methods of bibliometric analysis for determining vectors of green competitiveness concept development. The hypothesis of the study is the growing tendency of analysing sustainable competitiveness by scientists. In this order, a bibliometric analysis of the spread of the concept of «green competitiveness» in scientific articles indexed by the Scopus database was performed. The authors reviewed about 30000 papers from Scopus base in the period from 1996 till 2019. The Scopus screening tools showed that in 2004 the number of articles that focused on green competitiveness began to increase. On the international level, the investigated area was represented by the next countries: the United States, China, India, Great Britain, Taiwan. Using the VOS viewer program were identified the main clusters of the scientific papers, which have investigated green competitiveness with the interconnection of such categories: green marketing, green innovation and sustainable development. The findings could be used for improving the basis for the creation of the strategies for green competitiveness promotion.
\end{abstract}

\section{Introduction}

The development of the business sector today is described by the tendency of many enterprises to promote environmentally friendly strategies, to implement of sustainable development goals, which will help to solve the global and local environmental problems, to reduce anthropogenic pressure on the environment, to save resources, to form competitive development of the country and business sector as a whole.

Building the conceptual foundations for the development of green competitiveness in the context of the green economy and the use of appropriate marketing tools and promotion requires, above all, research and formation of its terminological basis.

Current development trends are characterised by increasing consumption of green products and services, implementation more than one of the distribution channels for green products promotion [1-4]. The key indicators which determine the efficiency of countries and enterprises are: economic, social, environmental, technological, managerial, marketing, innovative etc. [511]. The authors in the papers [12-20] investigated the influence of different modern economic instruments on companies' sustainability. Some of the papers [21-28] analysed the interconnection between macroeconomic and environmental indicators. The researches [29-32] justified why marketing factors of the competitive strengths' formation have a significant value for creating marketing strategies for different economic levels. At the same time, many scientific articles describe linkages between environment and economic indicators [33-37].

The paper [39] concluded that the competitiveness indicator is determined mainly by the social and ecological determinants. Their authors emphasise that population health creates the ability to perform work effectively, to receive adequate cultural and social security, and to live in an environmentally friendly environment.

Nonetheless, the market positioning today determined by the company's relation to environment problem, resource efficiency, production and promotion green goods and services [40-43]. Thus, it is essential to study the development of the concept of green competitiveness in the context of creating the theoretical background of their str strengthening.

\section{Methodology}

For the analysis were chosen the following keywords: "competitiveness", "greening", "policy". The research process was divided into two steps: were defined the basic clusters and their scale; was analysed the central cluster with the dynamics of scientific publications, their

\footnotetext{
${ }^{*}$ Corresponding author: o.chygryn@econ.sumdu.edu.ua
} 
affiliation and contribution of countries and individual scientists. The analysing process was done by providing the software of VOSviewer using the dates from the Scopus, which allowed to allocate and visualise the network of definitions and co-citation during the investigation of the development green competitiveness concept.

\section{Research results}

The necessity for the correct use of appropriate terms and determination of cross-sector areas of research has led to the using methods of bibliometric analysis. The international scient metric database Scopus was chosen as the information base of the study. In order to understand the context of scientific development of the topic of greening competitiveness, we analysed the connections between the key categories "competitiveness", "greening", "policy". For the corresponding analysis were analysed the scientific publications of the Scopus database from 1996 to 2019 (Fig. 1). The paper analysed about 30,000 scientific papers during the identified period.

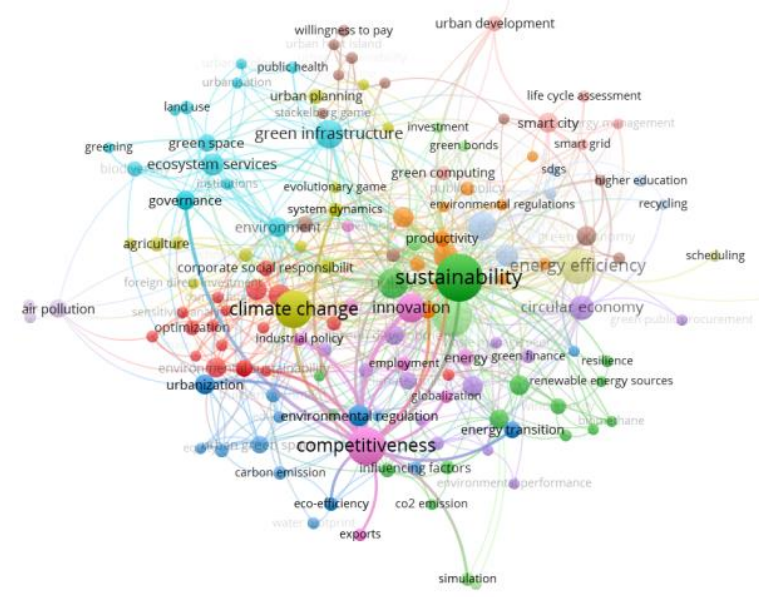

Fig. 1. The results of network relationships analysis of the key categories in scientific publications on the greening of competitiveness

Source: composed by the authors using VOSviewer 1.6.13

The main purpose of the analysis is to investigate the linking between the categories: competitiveness and the concepts associated with the processes of greening. Thus, the analysis showed the existence of the three most important conditional clusters related to the categories "competition", "climate change", "sustainability". The basic first cluster "competition" includes the following concepts: "environmental regulation", "environmental efficiency", "sustainability", "climate change", "productivity", "management", "industrial policy". The second cluster "climate change" includes such basic concepts as "economic growth", "environment", "ecosystem services", "green infrastructure", "green finance", "green bonds", "energy policy", "green information systems". The third cluster "sustainability" combines the following categories: "climate change", "sustainable development", "alternative energy", "competition", "efficiency", "environmental policy", "energy efficiency", "green infrastructure" and so on.

The relevant results of the analysis indicate a close correlation between the category of competitiveness, sustainable development, environmental regulation, climate change, etc. It stated a similar trend associated with the greening of management and production processes, the formation of a global market space focused on the functioning of a competitive environment based on the principles of sustainable development.

Accordingly, it determined the relevance of the analysis of the features and specifics of using in scientific publications the category "green competitiveness" to verify the ways of future research.

The study of relevant trends was conducted in the following sequence:

- monitoring of articles in the scientometric database Scopus by keywords "green competitiveness", "green marketing", "green innovations";

- the obtained data were grouped for further systematisation according to the criteria of chronology, affiliation, areas of use;

- the analysis of citation of scientific articles in the corresponding subject to determine authoritative scientists in the relevant branch;

- formed the system of co-citation of authors, identified the key categories which are the most used, interconnected with researches of green competitiveness; - clustering of terms according to the chronology of publications, their network visualisation of terms (frequency of use and relationship);

- performed a network analysis, which results allow to identify the relationship between green competitiveness and other areas of research, that confirmed the hypothesis of the relationship between competitiveness and green growth and sustainable development.

Thus, the corresponding request in the Scopus database confirmed the existence of scientific interest in the relevant topics in recent years (Fig. 2).

In total, the paper studied about 2,000 academic documents for the period from 1995 to 2019. The findings showed that the number of publications on the greening of marketing and competitiveness has grown since 1998.

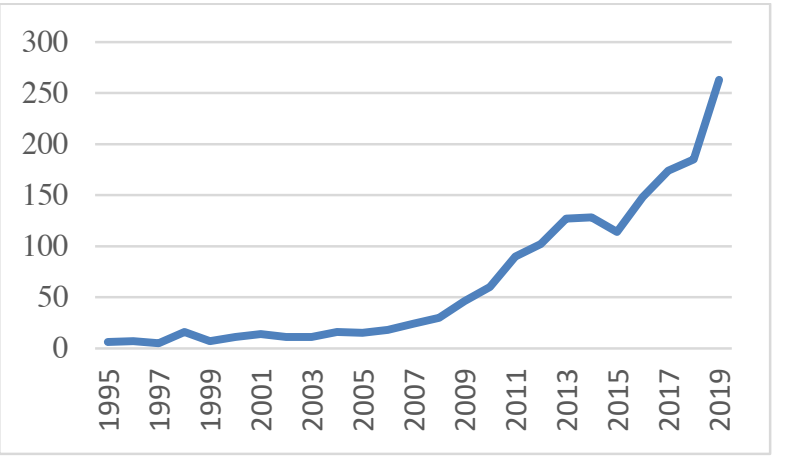

Fig. 2. Dynamics of scientific publications in the field of green competitiveness

Source: composed by the authors, based on the Scopus database 
At the same time, in 2016, part of the research moved to the study of green competitiveness. It could be explained by the actualisation of environmental issues (signing in December 2015 of the Paris Agreement "On Climate Change"), the expansion of research in the field of environmental degradation, natural resources depletion, increasing inequality, increasing climate change and more. Besides, in 2019, compared to 2000, the number of scientists who studied the greening of competitiveness increased more than 20 times. Further analysis of scientific publications on the topic of green competitiveness allowed us to identify areas of research where there are relevant academic developments (Fig. 3).

The diagram in Figure 3 describes the corresponding cross-sector study of the greening competitiveness processes. Thus, the main areas of research are business and management - 29\%; environmental sciences - 15\%; social sciences - 14\%, engineering sciences - 11\%; economics - 9\% and others (energy, computer, decision making, biological, materials science) - $22 \%$.

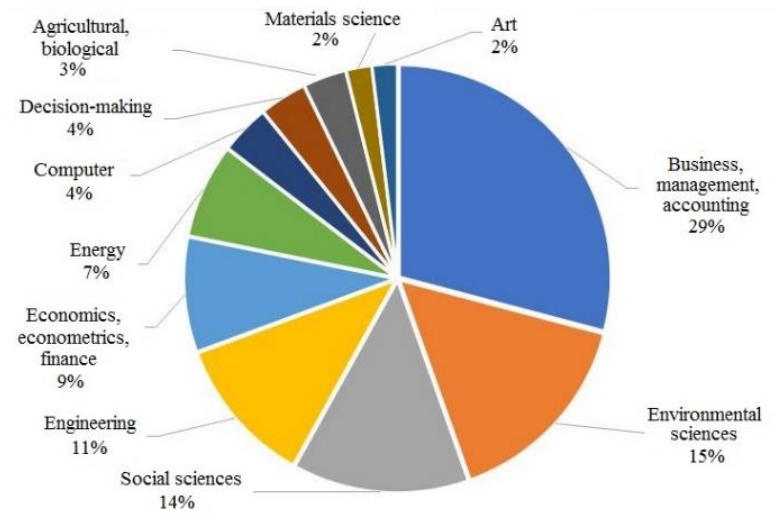

Fig. 3. Fields of green competitiveness research Source: composed by the authors, based on the Scopus database

Cross-country analysis shows that reliable researches are concentrated in the United States, China, India and the United Kingdom (Fig. 4).

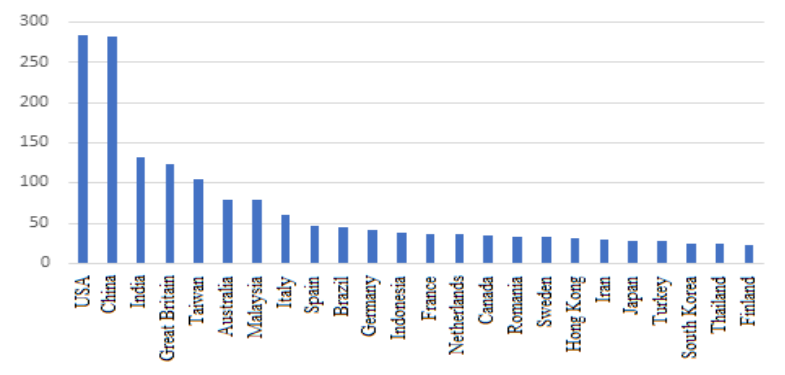

Fig. 4. International affiliation of green competitiveness research

Source: composed by the authors, based on the Scopus database

Thus, a significant share of research is devoted to the topic of green competitiveness. Namely, determining the role of perception of green products, environmental risk assessment and increasing green confidence. Innovative are studies on the green organisational identity of companies, the development of proactive and reactive innovations, the expansion of the market for green certificates [46, 47]. Noteworthy are scientific publications on sectoral aspects of the development and promotion of green marketing.

Figure 5 shows the contribution of individual researchers in the field of green competitiveness research.

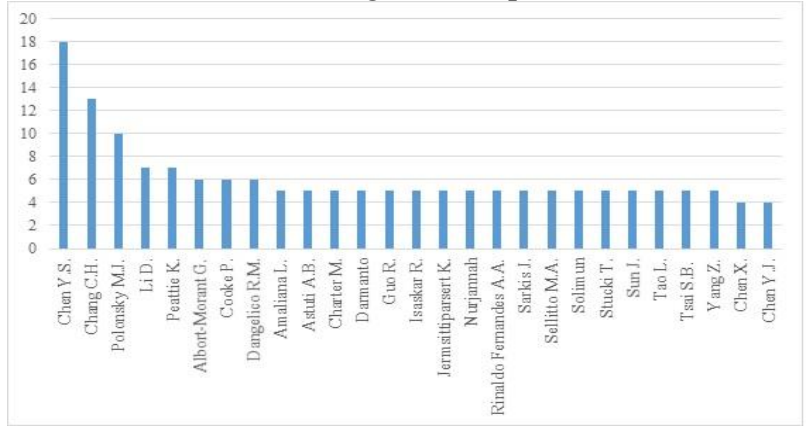

Fig. 5. Contribution of individual scientists in the field of green competitiveness research

Source: composed by the authors, based on the Scopus database

Scientists from Harbin University (China) [48, 49] explore the features of the green innovation promotion in the context of green competitiveness development.

Analysis of the contribution of authors (Fig. 5) showed that the leading positions belong to scientists from Taiwan $[50,51]$ in third place are scientists from Australia.

The formation of the methodological basis and theoretical foundations of the chosen topic requires the study of publication features. It is interesting to analyse the TOP-5 scientific journals with published scientific articles on environmental marketing and green competitiveness (Table 1).

Table 1. Ranking of the most productive scientific journals by the number of articles on the green competitiveness topic

\begin{tabular}{|c|c|c|c|c|c|}
\hline & Journal title & $\begin{array}{c}\text { Cite } \\
\text { score } \\
2018 \\
\end{array}$ & $\begin{array}{l}\text { SJR } \\
2018\end{array}$ & $\begin{array}{l}\text { SNIP } \\
2018\end{array}$ & $\begin{array}{c}\text { Number } \\
\text { of } \\
\text { articles }\end{array}$ \\
\hline 1 & $\begin{array}{l}\text { Journal of Cleaner } \\
\text { Production }\end{array}$ & 7,32 & 1,620 & 2,308 & 78 \\
\hline 2 & Sustainability & 3,01 & 0,549 & 1,169 & 58 \\
\hline 3 & $\begin{array}{c}\text { Business Strategy } \\
\text { and the Environment }\end{array}$ & 7,93 & 2,166 & 2,488 & 47 \\
\hline 4 & $\begin{array}{c}\text { Journal of Business } \\
\text { Ethics } \\
\end{array}$ & 4,46 & 1,860 & 2,006 & 21 \\
\hline 5 & $\begin{array}{c}\text { Journal of Consumer } \\
\text { Marketing }\end{array}$ & 2,17 & 0,653 & 0,967 & 18 \\
\hline 6 & $\begin{array}{c}\text { Top Conference } \\
\text { Series Earth and } \\
\text { Environmental } \\
\text { Science } \\
\end{array}$ & 0,44 & 0,170 & 0,536 & 17 \\
\hline 7 & $\begin{array}{l}\text { Journal of Business } \\
\text { Research }\end{array}$ & 5,32 & 1,684 & 1,920 & 17 \\
\hline 8 & $\begin{array}{c}\text { Advanced Materials } \\
\text { Research } \\
\end{array}$ & 0,08 & 0,121 & 0,179 & 13 \\
\hline 9 & $\begin{array}{c}\text { Marketing } \\
\text { Intelligence and } \\
\text { Planning } \\
\end{array}$ & 2,49 & 0,580 & 1,033 & 13 \\
\hline 10 & $\begin{array}{l}\text { International Journal } \\
\text { of Consumer Studies }\end{array}$ & 2,11 & 0,595 & 0,973 & 11 \\
\hline
\end{tabular}


Source: composed by the authors, based on the Scopus database

Thus, high-ranking journals such as Cleaner Production, Sustainability, Business Strategy and the Environment, etc. were analysed. Relevant journals have high citation rates and are in high demand in the scientific community. According to the combination of two characteristics (number of articles and rating of the journal), the most influential in terms of the number of published articles on the green competitiveness topic is Journal of Cleaner Production, Sustainability.

The analysis of the most productive world universities, which study the relevant topics, showed that Chinese scientific institutions provide active dynamic publishing activity: China Science Foundation, Fundamental Science Funds of Central Universities, Humanities and Social Science Foundation of the Ministry of Education of China, Doctoral Science Foundation, National Aerospace Science Foundation (Table 2).

Table 2. Ranking of universities by the number of articles devoted to the study of green competitiveness

\begin{tabular}{|c|c|c|c|}
\hline & Scientific institution & Country & $\begin{array}{c}\text { Number of } \\
\text { publications }\end{array}$ \\
\hline 1 & $\begin{array}{c}\text { Natural Sciences } \\
\text { Foundation }\end{array}$ & China & 85 \\
\hline 3 & $\begin{array}{c}\text { Fundamental research } \\
\text { funds of central } \\
\text { universities }\end{array}$ & China & 19 \\
\hline 4 & $\begin{array}{c}\text { Humanitarian and Social } \\
\text { Science Foundation of the } \\
\text { Ministry of Education }\end{array}$ & China & 14 \\
\hline 5 & $\begin{array}{c}\text { Doctoral Research } \\
\text { Foundation }\end{array}$ & China & 11 \\
\hline National Aerospace & China & 11 \\
\hline
\end{tabular}

Source: composed by the authors based on the Scopus database

Thus, the most cited publications are presented by scientists working in scientific institutions in China.

A thorough study of the links between related concepts of green competitiveness, the analysis of the thematic focus of research, the authorship of publications, required the using of appropriate software VOSviewer. With the help of the corresponding program, we carried out the analysis of thematic vectors of scientific papers, which allowed building a terminological map based on the joint appearance of terms in the titles and annotations of articles. The analysis allowed determining the system of clusters of scientific publications, which are devoted to the issue of green competitiveness (Fig. 6).

Thus, the largest cluster (red cluster) related to the category of environmental marketing includes the following concepts: green marketing strategies, green consumer, circular economy, green development, green technologies, renewable energy, environmental policy, corporate social responsibility, green management supply chain, consumer behaviour, green goods, innovation, marketing strategies.

The second-largest cluster related to the category of green innovation includes the following concepts: efficiency of green innovation, corporate sustainability, recycling, green supply chain, energy efficiency, environmental regulation, green product, climate change. The third cluster related to the concept of sustainable development and includes the following categories: environment, innovation, green demand, ecological consumption, green economy, green competitiveness, environmental awareness, environmental responsibility, etc. It should be noted that all three clusters are close to each other and are primarily related. The appropriate location of the primary clusters determines the close systemic relationships between the main determinants of clusters. It proves that green competitiveness is a category of green marketing and determine the level of development and promotion of green innovations in society.

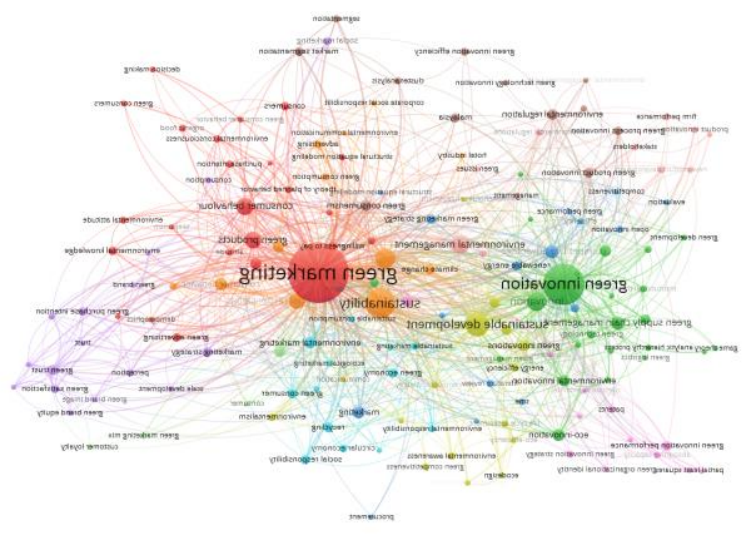

Fig. 6. Terminology map of the most common categories in publications on green competitiveness

Source: composed by the authors using VOSviewer 1.6.13

Besides, the results of the visualisation proved that a wide range of authors had studied the category of green marketing. At the same time, green competitiveness, environmental awareness, environmental responsibility are new relevant areas of research. Figure 7 shows the relationship between green competitiveness, green marketing and eco-innovation.

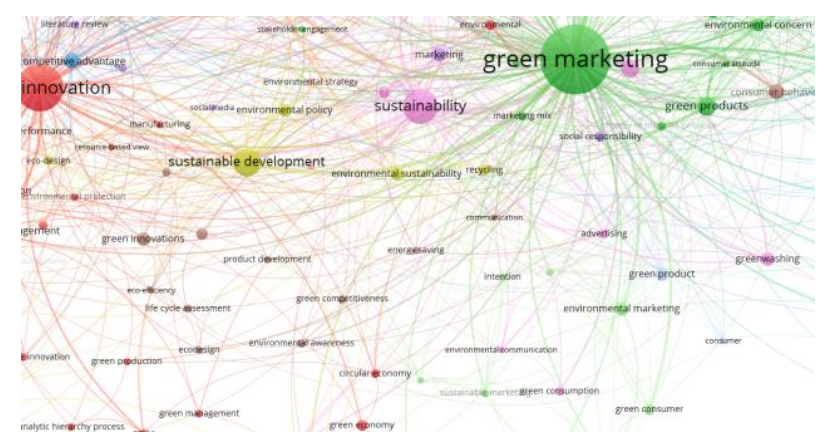

Fig. 7. Visualisation of mutual citation of scientific publications on the topic of green competitiveness with the nearest areas of research

Source: composed by the authors using VOSviewer 1.6.13

Besides, VOSviewer software also provides the ability to display the time horizon of the appearance of the studied categories, which are more common in scientific 
publications of the Scopus database (Fig. 8).

Thus, the approximation to the blue colour in the figure indicates a greater "maturity" of the publication, and respectively, scientific articles close to the "yellow colour" are more modern. Based on the results of visual reflection of the time actualisation of the categories of green competitiveness, it concludes that the first studies were devoted to the topic of green marketing, and then the orientation shifted to the field of green innovation. At the same time, publications devoted directly to green competitiveness have been appearing since 2017 .

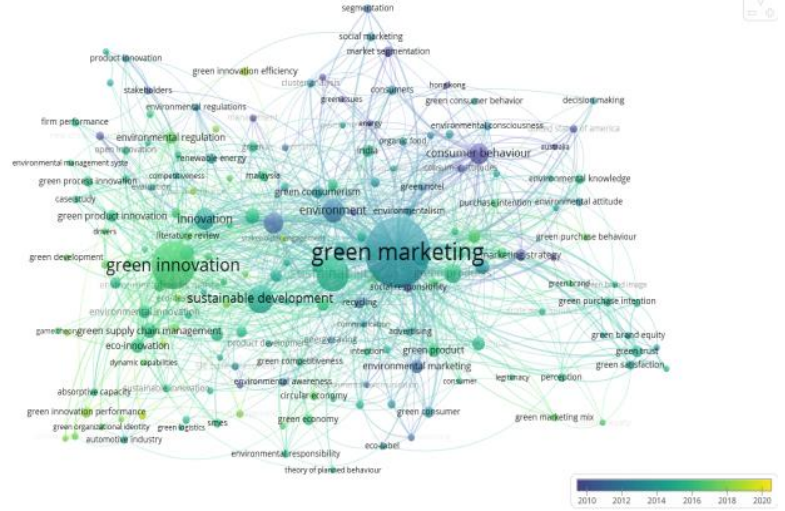

Fig. 8. Terminological map of the categories that are most common in publications on green competitiveness in the period from 2010 to 2019

Source: composed by the authors using VOSviewer 1.6.13

At the same time, terminological visualisation allows us to explore the features of citation between scientists in the relevant field of research. Figure 9 identifies five clusters. In the first cluster, the most authoritative authors are from the National University of Taipei (Taiwan) Chen Y. His scientific publications [44, 45] are devoted to issues of environmentally friendly consumer behaviour, environmental trust and green brand management.

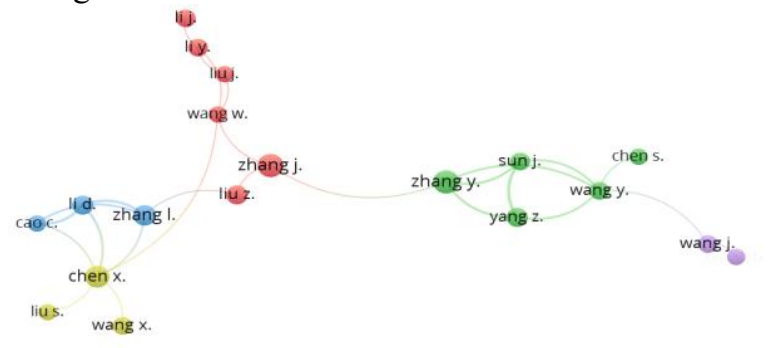

Fig. 9. Visualisation of the network of the most cited scientists in the field of green competitiveness

Source: composed by the authors using VOSviewer 1.6.13

In the second cluster, the most cited is the author Li D. from the Central Southern University (China), whose research papers $[46,47]$ are devoted to green innovations and assessing their profitability for corporations. In the third cluster, scientific articles by Zhang D. [48, 49] are devoted to regulating green innovations and assessing the side effects of green consumer integration. In the fourth cluster, the works of scientist Chen S. [50, 51] from the International Finance Institute of Guangzhou University (China) are noticeable, where the issues of financing green innovations are studied. The author Wang D. from the fifth cluster devoted his work [52] to determine the impact of green marketing on the performance of companies.

\section{Conclusions}

Thus, the content analysis of the most cited works, the generalisation of the results of data processing by VOSviewer 1.6.13 allowed to draw the following conclusions. The analysed scientific publications on the topic of green competitiveness testify to the cross-sector and multidisciplinary nature of existing research. The essential category is primarily related to the concepts of environmental marketing, green innovation and sustainable development. Besides, they also explore select areas such as behavioural economics, ecological trust management, social responsibility, mix marketing, stakeholder theory, cycle theory, and others. Research in the field of green competitiveness has become widespread over the past five years. The increasing dynamism explains the intensity of relevant research. At the same time, related industries that can become supportive in the formation of green competitiveness are digital and social marketing, development of social networks, stakeholder theories, environmental management and audit, information and Internet technologies. The analysis of geographical affiliation showed the concentration of a significant amount of research on green competitiveness in scientific institutions in China.

\section{Funding}

This research was funded by the grant from the Ministry of Education and Science of Ukraine №0119U101860 and № 0120U102002.

\section{References}

1. Aliyas, I. Evaluation of applications of sustainable agricultural development in Iraq. SocioEconomic Challenges, 2(2), 75-80 DOI:10.21272/sec.2(2).75-80.2018

2. Cebula, J., Chygryn, O., Chayen, S.V., Pimonenko, T. Biogas as an alternative energy source in Ukraine and Israel: Current issues and benefits, International Journal of Environmental Technology and Management, 21 (5-6), pp. 421-438 (2018). DOI:10.1504/IJETM.2018.100592

3. Hrytsenko, L. Rationale for priority sources of investment support of the national economy of Ukraine. Actual Problems of Economics, 159(9), 8491 (2014)

4. Dkhili, H. Environmental performance and institutions quality: evidence from developed and developing countries. Marketing and management of innovations, 3, 333-344 (2018). DOI: $10.21272 / \mathrm{mmi} .2018 .3-30$

5. Bilan, Y., Lyeonov, S., Stoyanets, N., Vysochyna, A. The impact of environmental determinants of 
sustainable agriculture on country food security. International Journal of Environmental Technology and Management, 21(5-6), 289-305 (2018). DOI: 10.1504 / IJETM.2018.100580

6. Bilan, Y., Pimonenko, T., Starchenko, L. Sustainable business models for innovation and success: Bibliometric analysis. E3S Web of Conferences (2020)

7. Bilan, Y., Vasylieva, T., Kryklii, O., Shilimbetova, G. The creative industry as a factor in the development of the economy: Dissemination of european experience in the countries with economies in transition. Creativity Studies, 12(1), 75-101 (2019). DOI: https://doi.org/10.3846/cs.2019.7453

8. Boiko, A., Samusevych, I. The role of tax competition between the countries of the world and the features of determining the main tax competitors of Ukraine among the European countries. Financial markets, institutions and risks, 1(1), $72-79$ (2017). DOI: 10.21272/fmir.1(1).72-79.2017

9. Chygryn, O., Pimonenko, T., Lyulyov, O., Goncharova, A. Green bonds like the incentive instrument for cleaner production at the government and corporate levels: Experience from EU to Ukraine. Journal of Environmental Management and Tourism, 9(7), 1443-1456 (2018). DOI: https://doi.org/10.14505//jemt.v9.7(31).09

10. Masharsky, A., Azarenkova, G., Oryekhova, K., Yavorsky, S. Anti-crisis financial management on energy enterprises as a precondition of innovative conversion of the energy industry: case of Ukraine. Marketing and management of innovations, 3, 345354 (2018). DOI: 10.21272/mmi.2018.3-31

11. Rosokhata, A. Rating tendencies of the innovative development prognostication system at the industrial enterprises, Marketing and Management of Innovations, 2, 43-53 (2014)

12. Mentel, G., Vasylieva, T., Samusevych, Y., Pryymenko, S. Regional differentiation of electricity prices: Social-equitable approach. International Journal of Environmental Technology and Management, 21(5-6), 354-372 (2018). DOI: 10.1504/IJETM.2018.100583

13. Bilan, Y., Lyeonov, S., Lyulyov, O., Pimonenko, T. Brand management and macroeconomic stability of the country. Polish Journal of Management Studies, 19(2), 61-74 (2019). 10.17512/pjms.2019.19.2.05

14. Chygryn, O., Krasniak, V. Theoretical and applied aspects of the development of environmental investment in Ukraine. Marketing and management of innovations, (3), 226-234 (2015)

15. Chygryn, O., Pimonenko, T., Luylyov, O., \& Goncharova, A. Green Bonds like the Incentive Instrument for Cleaner Production at the Government and Corporate Levels Experience from EU to Ukraine. Journal of Advanced Research in Management, 9(7), 1443-1456 (2018). DOI: https://doi.org/10.14505//jemt.v9.7(31).09
16. Hens, L., Melnyk, L., Matsenko, O., Chygryn, O., Chamorro Gonzales, C. Green investing for sdgs: EU experience for developing countries. Marketing and Management of Innovations, 3, 272-284 (2019). DOI.org/10.21272/mmi.2019.3 - 21

17. Ibragimov, Z., Lyeonov, S., Pimonenko, T. Green investing for sdgs: EU experience for developing countries. Economic and social development (ESD 2019): 37th international scientific conference on economic and social development - socio economic problems of sustainable development (2019)

18. Kendiukhov, I., Tvaronaviciene, M. Managing innovations in sustainable economic growth. Marketing and management of innovations, 3, 33-42 (2017). DOI: 10.21272/mmi.2017.3-03

19. Lyeonov, S., Pimonenko, T., Bilan, Y., Štreimikiene, D., Mentel, G. Assessment of green investments' impact on sustainable development: Linking gross domestic product per capita, greenhouse gas emissions and renewable energy. Energies, 12(20), 3891

DOI:https://doi.org/10.3390/en12203891

(2019).

20. Lyulyov, O., Chygryn, O., Pimonenko, T. National brand as a marketing determinant of macroeconomic stability. Marketing and Management of Innovations, 3, 142-152 (2018). DOI: 10.21272/mmi.2018.3-12

21. Vasylieva, T., Lyeonov, S., Makarenko, I., Sirkovska, N. Sustainability information disclosure as an instrument of marketing communication with stakeholders: markets, social and economic aspects. Marketing and management of innovations, 4, 350357 (2017). DOI: 10.21272/mmi.2017.4-31

22. Shvindina, H., Coopetition as an emerging trend in research: Perspectives for safety \& security. Safety, 5(3) (2019). DOI: 10,3390 / safety5030061

23. Bilan, Y., Lyeonov, S., Vasylieva, T. Does tax competition for capital define entrepreneurship trends in Eastern Europe. Online Journal Modelling the New Europe, 27, 34-66 (2018). DOI:10.24193/OJMNE.2018.27.02

24. Bilan, Y., Raišienè, A., Vasylieva, T., Lyulyov, O., Pimonenko, T. Public Governance efficiency and macroeconomic stability: Examining convergence of social and political determinants. Public Policy and Administration, 18(2), 241-255 (2019). DOI: https://doi.org/10.13165/VPA-19-18-2-05

25. Bilan, Y., Vasylieva, T., Lyeonov, S., Bagmet, K. Institutional complementarity for social and economic development. Business: Theory and Practice, 20, 103-115 (2019). DOI: https://doi.org/10.3846/btp.2019.10

26. Bilan, Y., Vasylieva, T., Lyulyov, O., Pimonenko, T. EU vector of Ukraine development: Linking between macroeconomic stability and social progress. International Journal of Business and Society, 20(2), 433-450 (2019)

27. Vasylieva, T., Kuzmenko, O., Bozhenko, V., Kolotilina, O. Assessment of the dynamics of bifurcation transformations in the economy. CEUR 
Workshop Proceedings, 2422, 134-146 (2019)

28. Marcel, D.T.Am. Impact of the foreign direct investment on economic growth on the re-public of Benin. Financial Markets, Institutions and Risks, 3(2), 69-78 (2019)

DOI: http://doi.org/10.21272/fmir.3(2).69-78.2019

29. Ibragimov, Z., Vasylieva, T., Lyulyov, O. The national economy competitiveness: effect of macroeconomic stability, renewable energy on economic growth. International Scientific. Conference on Economic and Social Development (2019)

30. Ivanova, E., Kordos, M. Competitiveness and innovation performance of regions in Slovak republic. Marketing and management of innovations, 1, 145-158 (2017). DOI: 10.21272/mmi.2017.1-13

31. Khan, Y. The effectiveness of entrepreneurial activities for economic development: a route to innovation and job generation. SocioEconomic Challenges, 2(2), 34-40 (2018). DOI: $10.21272 / \mathrm{sec} .2(2) .32-40.2018$

32. Myroshnychenko, I., Makarenko, I., Smolennikov, D., Buriak, A. The approach to managing corporate social and environmental responsibility in manufacturing. EM Journal, 8(3), 740-748 (2019)

33. Rybina, O. Formation of the environmental marketing mechanism in the context of the sustainable development concept. Efektyvna ekonomika, vol. 1. (2020). DOI: 10.32702/23072105-2020.1.76

34. Kysil, T., Kolodka, A., Rosokhata, A. Import Substitutionas a Means of Image Forming: Prospects Forecast of Industrial Enterprises in Ukraine, Economics\&Sociology, 7, 123-135 (2014)

35. Lyulyov, O., Pimonenko, T., Stoyanets, N., Letunovska, N. Sustainable development of agricultural sector: Democratic profile impact among developing countries. Research in World Economy, 10(4), 97-105 (2019)

36. Pimonenko, T., Lyulyov, O., Chygryn, O., \& Palienko, M. Environmental Performance Index: relation between social and economic welfare of the countries. Environmental Economics, 9(3), 1 (2018). DOI:10.21511/ee.09(3).2018.01

37. Rosokhata, A. The methodical apparatus formation forecasting of the industrial enterprise innovative activity directions. Economics and Management, 2, 115-121 (2014)

38. Rui, L., Sineviciene, L., Melnyk, L., Karintseva, O., Lyulyov, O. Economic and environmental convergence of transformation economy: The case of China. Problems and Perspectives in Management, 17(3), 233-241 (2019). DOI http://dx.doi.org/10.21511/ppm.17(3).2019.19

39. Letunovska, N., Rybina, O. Comparison and forecast of determinant formation of a healthy region. Efektyvna ekonomika, vol. 4. (2020). DOI: $\underline{10.32702 / 2307-2105-2020.4 .62}$
40. Pimonenko, T., Bilan, Y., Horák, J., Starchenko, L., Gajda, W. Green brand of companies and greenwashing under sustainable development goals. Sustainability (Switzerland), 12(4) (2020). DOI: 10.3390 / su12041679

41. Shevchenko, T., Koblianska, I., Saher, L. Development of biodegradable municipal waste separate collection system in Ukraine to fulfill the requirements of the European union directives. Journal of Environmental Management and Tourism, 7(3), 361-369 (2016)

42. Yevdokimov, Y., Chygryn, O., Pimonenko, T., Lyulyov, O. «Biogas as an alternative energy resource for Ukrainian companies: EU experience». Innovative Marketing, 14(2), 7-15 (2018). DOI http: //dx.doi.org/10.21511 / яM.14 (2).2018.01

43. Chen, Y.-S., Huang, A.-F., Wang, T.-Y., Chen, Y.-R. Greenwash and green purchase behaviour: the mediation of green brand image and green brand loyalty. Total Quality Management and Business Excellence, 31(1-2), 194-209 (2020)

44. Chen, Y.-S., Lin, C.-Y., Weng, C.-S. The influence of environmental friendliness on green trust: The mediation effects of green satisfaction and green perceived quality. Sustainability (Switzerland), 7 (8), 10135-10152 (2015)

45. Chen, Y.-S., Chang, T.-W., Lin, C.-Y., Lai, P.-Y., Wang, K.-H. The influence of proactive green innovation and reactive green innovation on green product development performance: The mediation role of green creativity. Sustainability (Switzerland), 8 (10), 966 (2016). DOI:10.3390/su8100966

46. Zhang, L., Cao, C., Tang, F., He, J., Li, D. Does China's emissions trading system foster corporate green innovation? Evidence from regulating listed companies. Technology Analysis and Strategic Management, 31 (2), 199-212 (2019)

47. Li, D., Zheng, M., Cao, C., Chen, X., Ren, S., Huang, $\mathrm{M}$. The impact of legitimacy pressure and corporate profitability on green innovation: Evidence from China top 100. Journal of Cleaner Production, 141, 41-49 (2017)

48. Zhang, J., Liang, G., Feng, T., Yuan, C., Jiang, W. Green innovation to respond to environmental regulation: How external knowledge adoption and green absorptive capacity matter? Business Strategy and the Environment, 29 (1), 39-53 (2020a). DOI https://doi.org/10.1002/bse.2349

49. Zhang, J., Zhao, Y., Zhang, N., Feng, T., Zhao, C. The green spillover effect of green customer integration: Does internal integration matter? Corporate Social Responsibility and Environmental Management, 27(1), 325-338 (2020b)

50. Chen, S., Huang, Z., Drakeford, B.M., Failler, P. Lending interest rate, loaning scale, and government subsidy scale in green innovation. Energies, 12(23) (2019aa). DOI https://doi.org/10.3390/en12234431

51. Chen, S., Liao, G., Drakeford, B.M., Failler, P. The non-linear effect of financial support on energy 
efficiency: Evidence from China. Sustainability (Switzerland), $11 \quad$ (7), $1959 \quad$ (2019b). DOI: $10.3390 /$ su1 1071959

52. Han, M., Lin, H., Wang, J., Wang, Y., Jiang, W. Turning corporate environmental ethics into firm performance: The role of green marketing programs. Business Strategy and the Environment, 28 (6), 929938 (2019). 